\title{
Multiple molecular effect pathways of an environmental oestrogen in fish
}

\author{
Amy L Filby, Karen L Thorpe and Charles R Tyler \\ Environmental and Molecular Fish Biology Group, School of Biosciences, Hatherly Laboratories, University of Exeter, Prince of Wales Road, Exeter, Devon EX4 4PS, UK
}

(Requests for offprints should be addressed to A L Filby; Email: a.l.fillby@exeter.ac.uk)

\begin{abstract}
Complex interrelationships in the signalling of oestrogenic effects mean that environmental oestrogens present in the aquatic environment have the potential to disrupt physiological function in fish in a more complex manner than portrayed in the present literature. Taking a broader approach to investigate the possible effect pathways and the likely consequences of environmental oestrogen exposure in fish, the effects of $17 \beta$-oestradiol $\left(E_{2}\right)$ were studied on the expression of a suite of genes which interact to mediate growth, development and thyroid and interrenal function (growth hormone $\mathrm{GH}(\mathrm{gh}), \mathrm{GH}$ receptor (ghr), insulin-like growth factor (IGF-I) (igf1), IGF-I receptor (igf1r), thyroid hormone receptors- $\alpha$ (thra) and - $\beta$ $(t h r b)$ and glucocorticoid receptor $(g r))$ together with the expression analyses of sex-steroid receptors and ten other genes centrally involved in sexual development and reproduction in fathead minnow (fhm; Pimephales promelas). Exposure of adult fhm to $35 \mathrm{ng} \mathrm{E}_{2} / \mathrm{l}$ for 14 days induced classic oestrogen biomarker responses (hepatic oestrogen receptor 1 and plasma vitellogenin), and impacted on the reproductive axis, feminising 'male' steroidogenic enzyme expression profiles and suppressing genes involved in testis differentiation. However, $\mathrm{E}_{2}$ also triggered a cascade of responses for gh, ghr, igf1, igf1r, thra, thrb and gr in the pituitary, brain, liver, gonad and gill, with potential consequences for the functioning of many physiological processes, not just reproduction. Molecular responses to $E_{2}$ were complex, with most genes showing differential responses between tissues and sexes. For example, igf1 expression increased in brain but decreased in gill on exposure to $E_{2}$, and responded in an opposite way in males compared with females in liver, gonad and pituitary. These findings demonstrate the importance of developing a deeper understanding of the endocrine interactions for unravelling the mechanisms of environmental oestrogen action and predicting the likely health consequences.
\end{abstract}

Journal of Molecular Endocrinology (2006) 37, 121-134

\section{Introduction}

It is now firmly established that a wide range of natural and anthropogenic chemicals present in the aquatic environment have the capacity to disrupt the endocrine system and, in turn, alter physiological function (Tyler et al. 1998). Many of these effects are as a consequence of exposure to chemicals with oestrogenic activity, so-called environmental oestrogens (for a review, see Sonnenschein \& Soto 1998). To date, studies on endocrine disruption have focused heavily on the ability of environmental oestrogens, acting via the oestrogen receptor, to alter reproductive function. This research focus has been driven by the finding that wild fish populations in UK rivers exposed to environmental oestrogens have altered sexual development (Jobling et al. 1998) and reduced fertility (Jobling et al. $2002 a, b)$.

There are, however, highly complex interrelationships, both within and between body tissues, mediating the endocrine control of reproduction, growth, development and other physiological processes in fish. Therefore, environmental oestrogens, and other endocrine-disrupting chemicals, have the potential to disrupt physiological function far more widely than directly through reproductive pathways in the gonad alone. Indeed, laboratory-based studies have shown that some environmental oestrogens not only affect reproduction of fish but can also impact on other endocrinemediated processes, including somatic growth (e.g. $17 \alpha$-ethinyloestradiol $\left(\mathrm{EE}_{2}\right.$; Versonnen \& Janssen 2004, Van den Belt et al. 2003), 4-tert-nonylphenol (NP; Dreze et al. 2000, Magliulo et al. 2002), methoxychlor (Magliulo et al. 2002)), osmoregulation (e.g. 17ßoestradiol $\left(\mathrm{E}_{2}\right)$ and NP (Madsen et al. 1997, Vijayan et al. 2001, Arsenault et al. 2004, Madsen et al. 2004, McCormick et al. 2005)), immune function (e.g. $\mathrm{E}_{2}$ (Wang \& Belosevic 1994, Hou et al. 1999, Law et al. 2001), $\mathrm{EE}_{2}$ (Law et al. 2001)), the stress response (e.g. $\mathrm{E}_{2}$ (Pottinger et al. 1996), NP (Magliulo et al. 2002), methoxychlor (Magliulo et al. 2002)) and embryonic development (e.g. $\mathrm{E}_{2}$ (Rasmussen et al. 2002), $\mathrm{EE}_{2}$ (Van den Belt et al. 2003)). The mechanisms by which these effects occur, however, are not fully known.

A mechanistic understanding of the interplay between components of the endocrine system together

DOI: 10.1677/jme.1.01997 Online version via http://www.endocrinology-journals.org 
with an appreciation of the wider effects of environmental oestrogens in the body are fundamental to better assess the potential health implications of exposure to environmental oestrogens. Molecular approaches (reviewed in Rotchell \& Ostrander 2003) provide tools for investigating the multiple pathways of chemical effect in the body and, potentially, for assessing responses to toxicants across entire biochemical pathways. Furthermore, changes in the expression of genes that play fundamental roles in development can signal for subsequent (and often latent) tissue- and organism-level effects. Thus, molecular approaches potentially provide rapid and sensitive diagnostic tools for subsequent physiological impacts.

In this work, we utilised a molecular approach to study the effects of an environmental oestrogen, $\mathrm{E}_{2}$, on the physiology of fish in a broader context than via reproductive pathways in the gonad alone. $\mathrm{E}_{2}$ was chosen for this work as it is used widely as a 'model' oestrogen to study the mechanisms of environmental oestrogen action and is one of the principal components responsible for oestrogenic activity in sewage treatment works effluents (Desbrow et al. 1998) and, therefore, has environmental relevance. The effects of exposure to $\mathrm{E}_{2}$ were determined on the expression of a suite of cDNAs for key hormones and receptors which interact to mediate somatic growth, development and thyroid and interrenal function (processes which involve endocrine axes that are known to interact with endogenous sex-steroid hormones, including oestrogens) together with analyses of the expression of sexsteroid receptors and genes that play central roles in reproduction. The study species used for this work was fathead minnow (fhm; Pimephales promelas), a model species for endocrine disruption research (reviewed in Ankley \& Villeneuve 2006).

Genes chosen for this study and that mediate somatic growth, development and thyroid and interrenal function were growth hormone $(g h)$, growth hormone receptor $(g h r)$, insulin-like growth factor-I (igfl), insulin-like growth factor-I receptor (igflr), thyroid hormone receptor- $\alpha$ (thra), thyroid hormone receptor$\beta$ (thrb) and glucocorticoid receptor $(g r)$. Growth hormone $(\mathrm{GH})$, synthesised predominantly by the somatotrophs of the anterior pituitary, is best known for its growth-promoting capabilities (Cavari et al. 1993), which are believed to be initiated principally through an intimate association with hepatic insulinlike growth factor-I (IGF-I), following GH-binding to membrane-bound GH receptors (GHRs) (reviewed in Kopchick \& Andry 2000). However, GH participates in almost all major physiological processes in fish including osmo- and iono-regulation (Sakamoto \& Hirano 1993), immune function (Perez-Sanchez 2000), reproduction (LeGac et al. 1993) and behaviour (Bjornsson 1997). Furthermore, both GH and IGF-I additionally function in an autocrine/paracrine manner and independently of one another in some target tissues (Jones \& Clemmons 1995, Harvey et al. 1998, Butler \& Le Roith 2001). Thyroid hormone receptors (THRs) mediate the effects of the thyroid hormones, thyroxine $\left(\mathrm{T}_{4}\right)$ and 3,3',5-triiodo-L-thyronine $\left(\mathrm{T}_{3}\right)$ in fish (Lazar 2003) and, as for GH, have the ability to regulate a wide range of cellular functions, including growth, development, differentiation, metabolism and maintenance of homeostasis, in virtually every tissue (Brent 1996). In fish, especially crucial roles of THRs have been recognised in early development and metamorphosis (Power et al. 2001). Glucocorticoid receptors (GRs) are the principal receptors mediating the effects of glucocorticoids, the principle one of which in fish is cortisol $(\mathrm{F})$. In fish, the well-established roles of $\mathrm{F}$ are in metabolism (many of which characterise the stress response; Wendelaar Bonga 1997), but it also has roles in growth, reproduction, larval development, cognition and immune function, and it mediates some of the processes traditionally thought to depend on mineralocorticoids, such as salt balance (reviewed in Mommsen et al. 1999).

Genes chosen for study that mediate sexual function included sex-steroid receptors, steroidogenic enzymes and other genes known to play roles in sexual differentiation and sexual development. The sexsteroid receptor genes were the three oestrogen receptor subtypes: oestrogen receptor 1 (esrl; formerly oestrogen receptor $\alpha$ ), oestrogen receptor $2 \mathrm{a}$ (esr $2 a$; formerly oestrogen receptor $\beta 2$ or $\gamma$ ) and oestrogen receptor $2 \mathrm{~b}$ (esr $2 b$; formerly oestrogen receptor $\beta$ ) and the androgen receptor (ar), which function as ligand-dependent transcription factors to regulate the expression of oestrogen and androgen target genes (reviewed in Tsai \& O'Malley 1994). The genes that play roles in sex-steroid synthesis were cytochrome P450 17 (cyp17), cytochrome P450 19a (cyp19a) and cytochrome $\mathrm{P} 450$ 19b (cyp19b), steroidogenic acute regulatory protein (star), hydroxysteroid 11- $\beta$-dehydrogenase 2 (hsd11b2) and hydroxysteroid 17- $\beta$-dehydrogenase $(h s d 17 b)$ and the others with established roles in sex differentiation and reproduction were anti-Mullerian hormone $(a m h)$, vasa homologue (vasa), doublesex and mab-3 related transcription factor $1(d m r t 1)$ and nuclear receptor subfamily-5 group A member 2 ( $n r 5 a 2$; formerly fushi tarazu factor 1 ( ftzfl) or steroidogenic factor $1(s f 1)$ ). There is no official gene nomenclature system for the fhm so, in this paper, the official gene and protein designations for the zebrafish (Danio rerio; http://zfin.org) have been adopted. In parallel with the effects of $\mathrm{E}_{2}$ on expression of the gene targets studied, induction of plasma vitellogenin $(\mathrm{Vg})$ and somatic weight and gonad growth were quantified as phenotypic effect measures of the oestrogen treatment. 
Table 1 Nucleotide sequences of real-time PCR primers, NCBI GenBank accession numbers, real-time PCR product sizes, annealing temperatures, and efficiencies $(E)$ for target genes

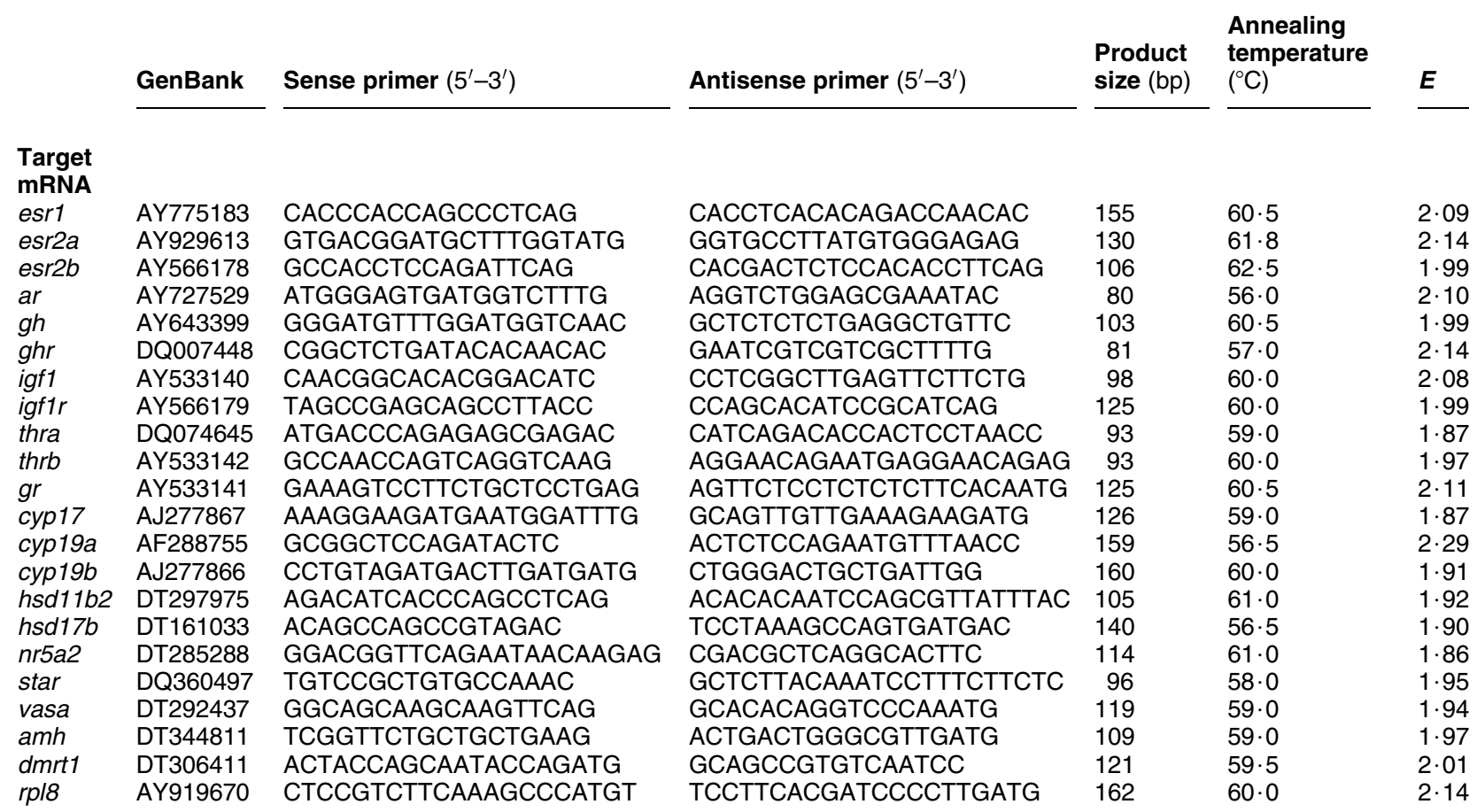

\section{Materials and methods}

\section{Test species}

The fhm used in this study were bred at the Brixham Environmental Laboratory, Brixham, Devon, UK. Fish were maintained under flow-through conditions in dechlorinated water at $25 \cdot 0 \pm 1{ }^{\circ} \mathrm{C}$ with a $16 \mathrm{~h}$ light: $8 \mathrm{~h}$ darkness photoperiod. Fish were fed adult Artemia sp. twice daily and Ecostart $17 \quad 1.0 \mathrm{~mm}$ fish food pellets (Biomar Ltd., Brande, Denmark) once daily. All animaluse protocols were carried out ethically in accordance with UK Home Office guidelines.

\section{$E_{2}$ exposure}

Duplicate tanks of adult ( $>150$ days post hatch) male and female fhm (eight males and eight females per tank) were exposed to $35 \mathrm{ng} \mathrm{E}_{2} / \mathrm{l}$ (98\% purity; lot 70K1206; Sigma) under flow-through conditions for a period of 14 days. The test concentration adopted in this work was within the concentration range found in European effluents (Desbrow et al. 1998, Ternes et al. 1999, Baronti et al. 2000, Rodgers-Gray et al. 2001). Duplicate tanks of the same numbers of fish were maintained in dilution water as controls.

To confirm the oestrogenic activity $\left(\mathrm{E}_{2}\right.$ equivalent) in the tanks, water samples were collected from the centre of each tank ( $350 \mathrm{ml} /$ tank) on a daily basis and the samples from the duplicate tanks were pooled to provide a composite sample $(700 \mathrm{ml} /$ treatment$)$. The sample was spiked with $0.5 \%$ methanol and extracted via peristalsis ( $5 \mathrm{ml} / \mathrm{min}$ ) onto preconditioned solid-phase extraction columns. $\mathrm{E}_{2}$ was eluted from the columns using $5 \mathrm{ml}$ methanol and stored at $-20^{\circ} \mathrm{C}$ for subsequent analysis. At the time of analysis, the methanol was removed under a stream of nitrogen and the extracts were resuspended in $5 \mathrm{ml}$ ethanol. The concentrated extracts were analysed using the recombinant yeast oestrogen screen (as described in Routledge \& Sumpter 1996). The $\mathrm{E}_{2}$ equivalents in the extracts were derived by comparison to a reference $\mathrm{E}_{2}$ standard curve. The limit of detection for the reference $\mathrm{E}_{2}$ standard curve was $10 \mathrm{ng} / 1 \mathrm{E}_{2}$.

Fish were sacrificed by a lethal overdose of anaesthesia $(500 \mathrm{mg} / 1 \mathrm{MS}-222$ (3-aminobenzoic acid ethyl ester) buffered to $\mathrm{pH} 7 \cdot 4$; Sigma) and a blood sample was collected from the heart of each fish into chilled heparinised syringes. The blood samples were centrifuged at $28000 \mathrm{~g}$. for $5 \mathrm{~min}$ and the plasma removed and stored at $-80{ }^{\circ} \mathrm{C}$ for subsequent measurement of $\mathrm{Vg}$, a biomarker of oestrogen exposure. $\mathrm{Vg}$ was measured in the plasma of all fish using a carp $\mathrm{Vg}$ ELISA validated for use with $\mathrm{fhm}(1 \mathrm{ng} / \mathrm{ml}$ detection limit; Tyler $e t$ al. 1999). All fish were measured for total length $(\mathrm{mm})$ and wet weight $(\mathrm{mg})$ and gonads were removed and weighed (to the nearest $0 \cdot 1 \mathrm{mg}$ ) for the 

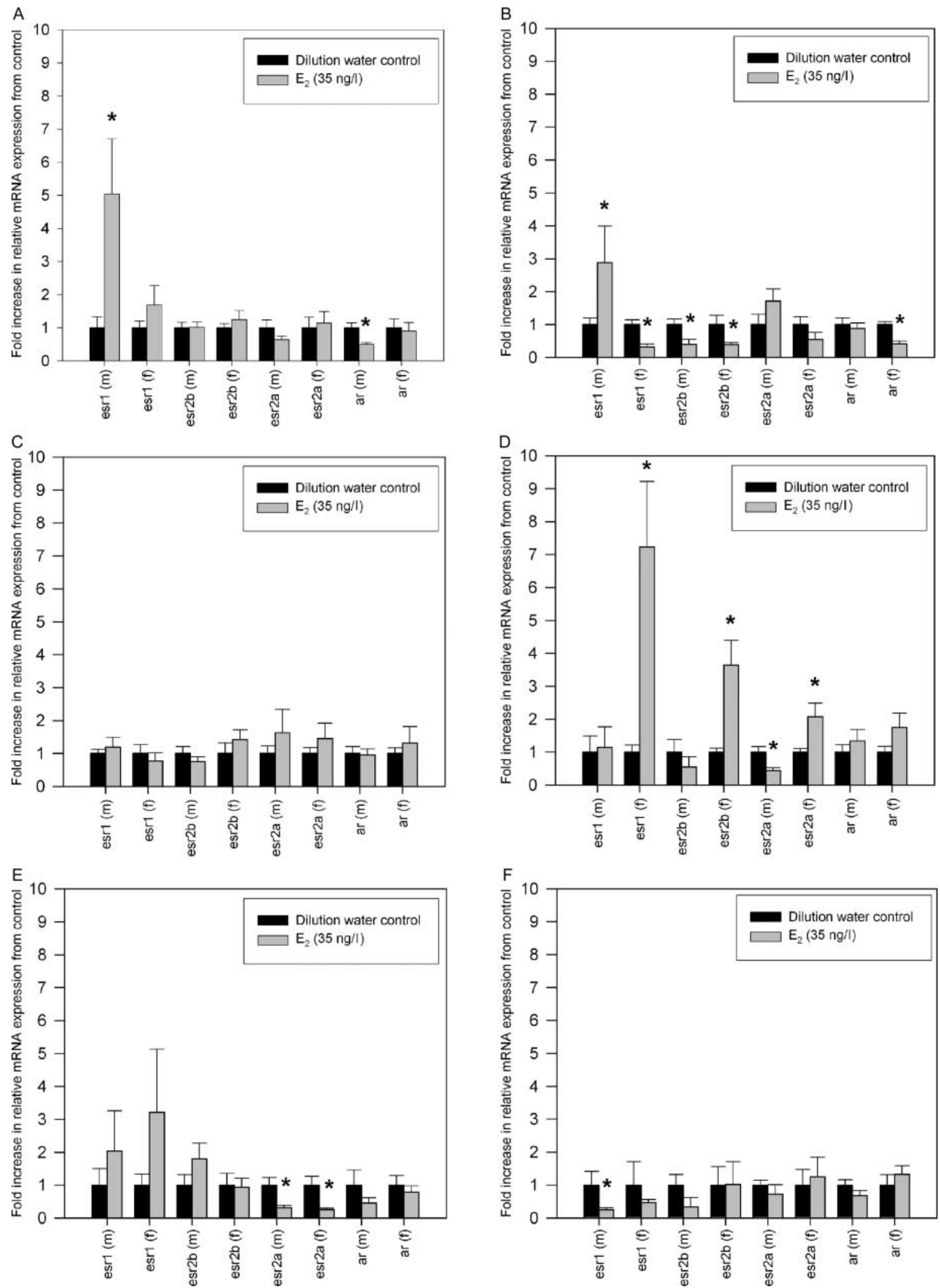
determination of gonadosomatic index $(\mathrm{GSI}) \quad(\mathrm{GSI}=$ (gonad weight/body weight) $\times 100$ ). Tissue samples (gonad, brain, pituitary (complete on lower skull plate), liver, gill and intestine) were collected from each fish from a single replicate tank, snap-frozen in liquid nitrogen and stored at $-80{ }^{\circ} \mathrm{C}$ until RNA extraction (within 1 month) for subsequent gene expression analyses.

\section{RNA extraction}

Total RNA was extracted from each tissue sample using Tri Reagent (Sigma) following the manufacturer's instructions. Total RNA concentration was estimated from absorbance at $260 \mathrm{~nm}\left(A_{260 \mathrm{~nm}}\right.$; GeneQuant; Amersham) and RNA quality was verified by electrophoresis on ethidium bromide-stained $1.5 \%$ agarose gels and by $A_{260 \mathrm{~nm}} / A_{280 \mathrm{~nm}}$ ratios $>1 \cdot 8$.

\section{Real-time PCR}

\section{Development of real-time PCR assays for target genes}

The assays for the fhm esrs were performed as previously described (Filby \& Tyler 2005). Primers specific for the other target cDNAs were designed with Beacon Designer 3.0 Software (Premier Biosoft International, Palo Alto, CA, USA) according to the manufacturer's guidelines and purchased from MWG-Biotech (Ebersburg, Germany). Assays were optimised and validated for real-time quantitative PCR using SYBR Green chemistry as described previously (Filby \& Tyler 2005). Assays had detection ranges of at least five orders of magnitude. Specificity of primer sets throughout this range of detection was confirmed by the observation of single amplification products of the expected size and melting temperature $\left(T_{\mathrm{m}}\right)$ and sequence. All assays were quantitative with standard curve (mean threshold cycle $\left(C_{\mathrm{t}}\right)$ vs $\log$ cDNA dilution) slopes of between $-2 \cdot 783$ and $-3 \cdot 722$, translating to high efficiencies $\left(E ; E=10^{(-1 / \text { slope })} ;\right.$ Rasmussen 2001) of $1 \cdot 86-2 \cdot 29$. Over the detection range, the linear correlation $\left(R_{2}\right)$ between the mean $C_{\mathrm{t}}$ and the logarithm of the cDNA dilution was $>0.99$ in each case. Primer sequences, NCBI GenBank accession numbers, PCR product sizes, PCR efficiencies and annealing temperatures are shown in Table 1.

\section{Real-time PCR analyses of the expression of target genes}

To analyse the expression of the target genes following exposure to $\mathrm{E}_{2}$, cDNA was synthesised from $1 \mu \mathrm{g}$ RQ1 DNase-treated (Promega) total RNA using random hexamers (MWG-Biotech) and Moloney-murine leukaemia virus reverse transcriptase (Promega), following the manufacturer's instructions. Real-time PCR using SYBR Green chemistry was performed for target genes with the iCycler iQ Real-time Detection System (Bio-Rad) as described previously (Filby \& Tyler 2005), using the appropriate annealing temperatures (Table 1). Relative quantitation via normalisation to a 'housekeeping' gene, which was measured in each sample, was performed as described previously (Filby \& Tyler 2005). We have previously validated the use of fhm ribosomal protein 18 (rpls) for normalisation between control and $\mathrm{E}_{2}$-treated fhm (AL Filby \& CR Tyler, unpublished observations) and applied this system here. Assays had a high level of precision and reproducibility with intraassay coefficient of variation (CV) of $2.42 \%(n=96)$. Interassay CV values were not measured because all of the samples for each tissue type for each exposure were run on the same plate.

\section{Data analysis}

Statistical differences in relative mRNA expression between experimental groups were assessed by Student's $t$-test. Non-normally distributed data were log-transformed prior to statistical analysis. All statistical analyses were performed using SigmaStat 2.03 Software (Jandel Scientific Software Chicago, IL, USA). All experimental data are shown as the mean \pm s.e.m. Differences were considered statistically significant at $P<0 \cdot 05$.

\section{Results}

The mean oestrogenic activity in the $\mathrm{E}_{2}$-treated tanks over the 14-day exposure period was $35 \cdot 2 \pm 14 \cdot 5 \mathrm{ng} / 1 \mathrm{E}_{2}$ equivalent, compared with $4.9 \pm 0.94 \mathrm{ng} / 1 \mathrm{E}_{2}$ equivalent in the control tanks. There were no effects of $E_{2}$ on fish growth. On day 14, wet weight of $E_{2}$-treated fish was $2 \cdot 10 \pm 0 \cdot 11 \mathrm{~g}$ (males) and $1 \cdot 00 \pm 0 \cdot 03 \mathrm{~g}$ (females), which was not significantly different from the wet weight of control fish (males, $2 \cdot 09 \pm 0 \cdot 12 \mathrm{~g}$; females, $1 \cdot 07 \pm 0 \cdot 05 \mathrm{~g}$ ). On day 14 , the total length of $\mathrm{E}_{2}$-treated fish was $58 \pm 1 \mathrm{~mm}$ (males) and $46 \pm 1 \mathrm{~mm}$ (females), which was not significantly different from the

Figure 1 Expression of key sex steroid receptors (fathead minnow (fhm) esr1, esr2b, esr2a, ar) in (A) liver, (B) gonad, (C) brain, (D) pituitary, $(E)$ intestine and $(F)$ gill of adult male $(m)$ and female $(f)$ fhm following waterborne exposure to $35 \mathrm{ng} 17 \beta$-oestradiol $\left(E_{2}\right) / /$. The results are represented as means \pm S.E.M. and expressed as fold-increase in relative mRNA expression from the control. Relative mRNA expression was determined as the ratio of target gene mRNA/rp/8 mRNA. Each treatment group consisted of eight male and eight female fish and each fish was analysed in duplicate. Statistically significant differences in fold-changes in relative gene expression levels between control and treated fish for each sex for each tissue type are denoted by an asterix $(P<0 \cdot 05$, Student's $t$-test). 
total length of control fish (males, $58 \pm 1 \mathrm{~mm}$; females, $45 \pm 1 \mathrm{~mm})$. GSI was unaffected by the short-term $\mathrm{E}_{2}$ treatment in males $(1 \cdot 2 \pm 0 \cdot 12$ in control males; $1 \cdot 20 \pm$ $0 \cdot 12$ in $\mathrm{E}_{2}$-treated males). However, ovary growth was reduced in $\mathrm{E}_{2}$-treated females $(15 \cdot 60 \pm 1 \cdot 04$ in control females; $9 \cdot 35 \pm 0 \cdot 88$ in $\mathrm{E}_{2}$-treated females; $P<0 \cdot 001$ ). There was a significant induction of plasma $\mathrm{Vg}$ in both male $(P<0 \cdot 001)$ and female $(P=0 \cdot 031)$ fish exposed to $\mathrm{E}_{2}$ (from $27 \cdot 16 \pm 7 \cdot 54 \mathrm{ng} / \mathrm{ml}$ in control males to $55 \cdot 30 \pm 3 \cdot 84 \mu \mathrm{g} / \mathrm{ml}$ in $\mathrm{E}_{2}$-treated males; from $408 \cdot 75 \pm 26 \cdot 92 \mu \mathrm{g} / \mathrm{ml}$ in control females to $617 \cdot 21 \pm$ $66 \cdot 66 \mu \mathrm{g} / \mathrm{ml}$ in $\mathrm{E}_{2}$-treated females).

\section{Expression of target genes following exposure to $E_{2}$}

Expression of target genes involved in reproduction, growth, development and thyroid and interrenal function, was determined by real-time PCR and compared with expression in untreated fish. Expression of target genes were measured in six tissues with the exception of $g h$ expression that was only analysed in pituitary and gonad, because it was undetectable in the other tissue types studied, and cyp17, cyp19a, cyp19b, hsd11b2, hsd17b, star, amh, vasa, dmrt1 and nr5a2 that were measured only in gonad.

\section{Expression of sex-steroid receptors}

Exposure to $\mathrm{E}_{2}$ was associated with changes in expression of fhm sex-steroid receptors in all tissues examined, except brain (Fig. 1). In liver (Fig. 1A), there was a significant induction (approximately fivefold) of esrl in male fish exposed to $\mathrm{E}_{2}(P=0 \cdot 041)$. There appeared to be a similar induction of hepatic esrl in female fish, but this difference was not statistically significant. Hepatic expression levels of esr $2 a$ and esr $2 b$ remained unchanged in $\mathrm{E}_{2}$-exposed fish. Expression of ar was down-regulated in $\mathrm{E}_{2}$-exposed fish, but this was only significant in males $(50 \%$ down-regulation, $P=0 \cdot 003$ ).

As in the liver, in the testis (Fig. 1B), there was a significant induction $(2 \cdot 8$-fold, $P=0 \cdot 04)$ of esr 1 . In contrast, in ovary, esrl was down-regulated $(P=0 \cdot 002)$ to $30 \%$ of the level observed in control fish. esr $2 b$ was also down-regulated $(60 \%, P=0.03)$ in the gonads of both male and female fish exposed to $\mathrm{E}_{2}$. Gonadal ar was down-regulated by $\mathrm{E}_{2}$, but this was only significant in female fish, where ar expression was $40 \%$ of that in control females $(P<0 \cdot 001)$.

In the pituitary (Fig. 1D), there was a large (sevenfold) up-regulation $(P=0 \cdot 001)$ in esrl expression in female fish but not in males. There was also an up-regulation in expression of both pituitary esr $2 a$ (twofold, $P=0 \cdot 04$ ) and esr $2 b(3 \cdot 5$-fold, $P=0 \cdot 017)$ in $\mathrm{E}_{2}$-exposed females. This contrasts with that which occurred in males where there was a $60 \%$ down-regulation $(P=0 \cdot 012)$ of pituitary esr $2 a$ and no significant change in expression of pituitary esr $2 b$.

In the intestine (Fig. 1E), the only statistically significant changes in expression of steroid hormone receptors following exposure to $\mathrm{E}_{2}$ were for esr $2 a$ which was down-regulated in both males $(P=0.017)$ and females $(P=0.025)$, to 23 and $27 \%$ of their control levels respectively. In the gill (Fig. $1 \mathrm{~F}$ ), there was a down-regulation of esr 1 , but this was only significant in male fish (to $40 \%$ of its level in control fish, $P=0 \cdot 03$ ). Expression levels of all other branchial steroid hormone receptors remained unchanged.

\section{Expression of genes involved in reproduction}

Exposure to $\mathrm{E}_{2}$ was associated with changes in the gonadal expression of seven of the ten genes involved in reproduction (Fig. 2). For those genes involved in gonadal steroidogenesis, cyp 17 was down-regulated in $\mathrm{E}_{2^{-}}$ exposed males (to $16 \%$ of the control level; $P=0 \cdot 020$ ), but highly (fivefold) up-regulated in $\mathrm{E}_{2}$-exposed females $(P=0 \cdot 049)$. In contrast, cyp19b was between two- and threefold up-regulated in both $\mathrm{E}_{2}$-exposed males $(P=0 \cdot 025)$ and females $(P=0 \cdot 004)$, but $\mathrm{E}_{2}$ had no effect on $c y p 19 a$. $\mathrm{E}_{2}$ exposure resulted in a decrease in the expression of $h s d 11 b 2(P=0 \cdot 023)$ in males but had no effect in females. $\mathrm{E}_{2}$ also decreased $h s d 17 b(P=0 \cdot 001)$ expression in males, but while $h s d 17$ was $3 \cdot 5$-fold higher in $\mathrm{E}_{2}$-exposed females, a high degree of variation between individuals meant that this was not statistically significant. Expression of star in $\mathrm{E}_{2}$-exposed males was $30 \%$ of that in controls $(P=0 \cdot 046)$, amh in both $\mathrm{E}_{2^{-}}$ exposed males $(P=0 \cdot 038)$ and females $(P=0 \cdot 033)$ was only $50 \%$ of that in controls, and $n r 5 a 2$ in $\mathrm{E}_{2}$-exposed females was only $10 \%$ of that in control females $(P=0 \cdot 005)$. There were no statistically significant effects of $\mathrm{E}_{2}$ on expression of vasa or dmrt1 in either males or females.

\section{Expression of target genes involved in growth, development and thyroid and interrenal function}

Exposure to $E_{2}$ was associated with changes in expression of genes involved in growth, development and thyroid and interrenal function in all tissues examined except intestine (Fig. 3). In liver (Fig. 3A), the expression of $g h r$, thra and $g r$ remained unchanged following 14 days exposure to $\mathrm{E}_{2}$. Hepatic expression of igfl appeared to decrease (males, to $40 \%$ of the control level; females, to $80 \%$ of the control level) following exposure to $\mathrm{E}_{2}$, but this decrease was only significant in males $(P<0 \cdot 05)$. There appeared to be an induction (males, 1·2-fold; females, 3-2-fold) of hepatic igflr following exposure to $\mathrm{E}_{2}$, but this was only significant in females $(P<0 \cdot 001)$. Hepatic thrb expression was induced $(4 \cdot 3$-fold, $P=0 \cdot 012)$ by exposure to $\mathrm{E}_{2}$ in 


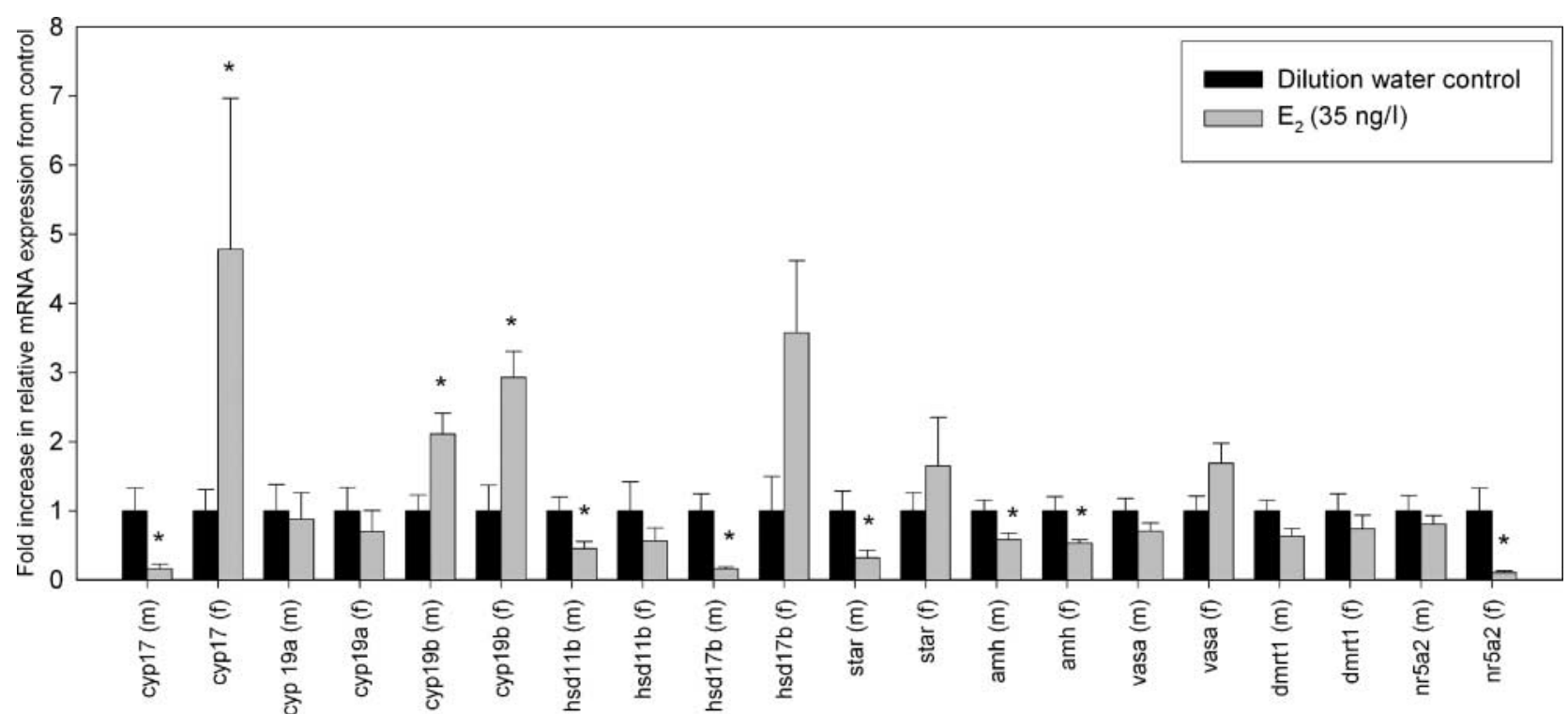

Figure 2 Expression of genes involved in sexual development and reproduction (fhm cyp17, cyp19a, cyp19b, hsd11b, hsd17b, star, amh, vasa, dmrt1, nr5a2) in gonad of adult male $(\mathrm{m})$ and female (f) fhm following waterborne exposure to $35 \mathrm{ng} 17 \beta$-oestradiol $\left(\mathrm{E}_{2}\right) / \mathrm{l}$. The results are represented as means \pm S.E.M. and expressed as fold-increase in relative mRNA expression from the control. Relative mRNA expression was determined as the ratio of target gene mRNA/rp/8 mRNA. Each treatment group consisted of eight male and eight female fish and each fish was analysed in duplicate. Statistically significant differences in fold-changes in relative gene expression levels between control and treated fish for each sex for each tissue type are denoted by an asterix $(P<0 \cdot 05$, Student's $t$-test).

male fish, but decreased (to $37 \%$ of the control level, $P=0 \cdot 003)$ in exposed females.

In gonad (Fig. 3B), the expression of all target genes with the exception of igflr was altered by exposure to $\mathrm{E}_{2}$ in at least one sex of fish. There were up-regulations in the expression of gonadal $g h$ and thrb in both males (gh 3.5-fold, $P=0 \cdot 005$; thrb 2.8-fold, $P=0 \cdot 009$ ) and females $(g h 2 \cdot 7$-fold, $P=0 \cdot 003$; thrb $2 \cdot 1$-fold, $P=0 \cdot 016$ ) exposed to $\mathrm{E}_{2}$. In contrast, gonadal ghr (to $31 \%$ of the control level, $P=0 \cdot 029$ ), igfl (to $14 \%$ of the control level, $P=0 \cdot 009$ ), thra (to $27 \%$ of the control level, $P<0 \cdot 001$ ) and $g r$ (to $28 \%$ of the control level, $P=0 \cdot 003$ ) were down-regulated by $\mathrm{E}_{2}$, but in females only.

In brain (Fig. 3C), the expression of all genes remained unaltered following exposure to $\mathrm{E}_{2}$ for 14 days, with the exception of $i g f 1$ which was significantly induced in both males $(1 \cdot 8$-fold, $P=0 \cdot 011)$ and females (fivefold, $P=0 \cdot 042$ ). In pituitary (Fig. 3D), the expression of $g h$, igflr and thrb remained unchanged following exposure to $E_{2}$. There were, however, changes in the expression of $g h r$, igfl, thra and $g r$, but the effects of $\mathrm{E}_{2}$ on these genes were sex specific. In males, there was suppressed pituitary expression of $g h r$ (to $47 \%$ of the control level, $P=0 \cdot 024$ ), igf 1 (to $25 \%$ of the control level, $P=0.015$ ) and $g r$ (to $51 \%$ of the control level, $P=0 \cdot 016)$. In females, in contrast, there was increased pituitary expression of $g h r$ (4-fold, $P=0 \cdot 045$ ), igf 1 (3-fold, $P=0 \cdot 017)$, thra (3.6-fold, $P=0 \cdot 03)$ and $g r$ $(2 \cdot 4$-fold, $P=0 \cdot 041)$.
In the gill of $\mathrm{E}_{2}$-exposed fish (Fig. 3F), igfl expression was undetectable in $25 \%$ of fish (igfl was detectable in all of the control fish) and, in the fish in which igfl expression was detectable, there was a down-regulation in expression in males (to $21 \%$ of the control level, $P=0.006$ ) and females (to $26 \%$ of the control level, $P=0 \cdot 029)$. There were also down-regulations in the expression of igflr (to $18 \%$ of the control level, $P<0.001$ ) and thra (to $43 \%$ of the control level, $P=0 \cdot 039$ ) in gills of male fish exposed to $\mathrm{E}_{2}$.

\section{Discussion}

As expected, the exposure of fhm to the environmental oestrogen $\mathrm{E}_{2}$ caused the induction of classic biomarkers of oestrogen exposure, most notably the hepatic esr 1 gene (in males) and the female yolk protein precursor Vg (in both sexes) (Sumpter \& Jobling 1995, MacKay et al. 1996). Moreover, in the gonad, $\mathrm{E}_{2}$ treatment was associated with alterations in the expression of sexsteroid receptors and genes centrally involved in reproductive function in a manner consistent with that expected for exposure to an oestrogen. In male $\mathrm{fhm}$, the exposure to $\mathrm{E}_{2}$ was associated with feminisation of the expression profiles for sex-steroid receptors and steroidogenic enzymes, consistent with published data on fhm and other teleost species (e.g. Govoroun et al. 2001, Halm et al. 2002, Baron et al. 2005). 

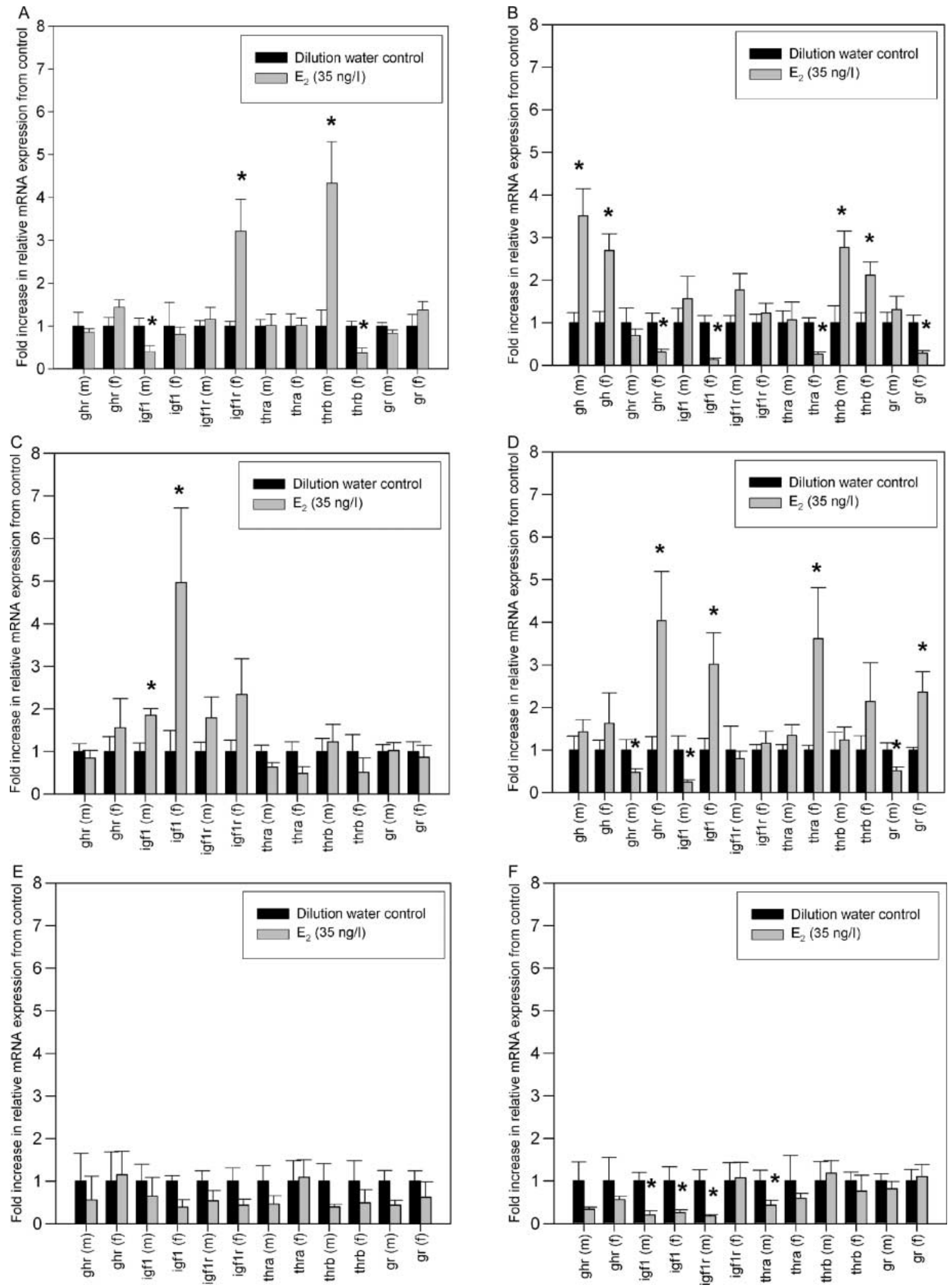
For example, $\mathrm{E}_{2}$-treated males had increased expression of esrl, normally higher in female fhm (Filby \& Tyler 2005), decreased expression of cyp17 and $h s d 11 b 2$, key enzymes in the production of androgens in males (Arai \& Tamaoki 1967, Conley \& Bird 1997) and increased expression of $c y p 19 b$, the enzyme responsible for the conversion (aromatisation) of androgens to oestrogens (reviewed in Simpson et al. 1994). Suppression of 'male' steroidogenic enzymes by oestrogens may be due to a negative feedback of $\mathrm{E}_{2}$ on folliclestimulating hormone (Fsh), but data from studies on trout instead supports a direct effect of $\mathrm{E}_{2}$ on the testis (Govoroun et al. 2001, Baron et al. 2005). In female fish, a stimulatory effect of $\mathrm{E}_{2}$ on gonadal $\mathrm{E}_{2}$ synthesis is implied by the increased expression of cyp17 (which, through its role in androgen production, is also indispensable for the production of oestrogens by cyp19) and increased expression of cyp19b. This is consistent with increased gonadal $\mathrm{E}_{2}$ production and plasma $\mathrm{E}_{2}$ levels in female mummichog exposed to environmentally relevant levels of oestrogen (MacLatchy et al. 2003).

Further, reproductive effect pathways of $\mathrm{E}_{2}$ are highlighted by down-regulation of amh (in males and females) and $n r 5 a 2$ (in females). Nr5a2 acts as a transcription factor to regulate many enzymes involved in steroid production (including cyp19), controls pituitary expression of the $f s h$ gene, and is a likely regulator of amh (reviewed in Liu et al. 1997), so its modulation by $\mathrm{E}_{2}$, therefore, has implications for both steroidogenesis and sex differentiation. Amh is best known for its role in males during early life in inhibiting the development of female primordial internal genitalia and diverting the steroidogenic pathway from oestrogens to androgens through inhibition of Fsh-stimulated cyp19a expression (reviewed in Josso et al. 1998). However, it also has roles in later life in folliculogenesis in females (Durlinger et al. 2002) and in negatively influencing development of the adult testis in males (Josso et al. 1998). As for amh, another testis differentiation gene, $d m r t 1$, was also apparently decreased by $\mathrm{E}_{2}$ in this study, consistent with current data showing $d m r t 1$ down-regulation by feminising agents (Marchand $e t$ al. 2000 ), but due to high variability the difference was not statistically significant in our study.

While the data on the reproductive axis provide valuable insight into oestrogen effect pathways in the gonad with likely reproductive consequences in the fhm, the effects seen are perhaps not especially surprising. $\mathrm{E}_{2}$ treatment, however, was also shown to lead to altered expression of genes involved in growth, development and thyroid and interrenal function throughout the body, indicating wider potential impacts on the physiological function of fish. Moreover, some of the effects seen on gene transcription were highly sex- and tissue-specific.

Although $\mathrm{E}_{2}$ had no effect on fish growth after 14 days of exposure (consistent with another short-term study on the effects of the $\mathrm{E}_{2}$-mimic $\mathrm{EE}_{2}$ on somatic growth in fhm; Panter et al. 2002), changes occurred in the expression of key growth-regulating genes in the liver. In particular, hepatic igfl expression was downregulated (in male fish) by $\mathrm{E}_{2}$, consistent with findings in other teleosts discussed previously. $\mathrm{E}_{2}$ is, in fact, a powerful regulator of pituitary $\mathrm{GH}$, paradoxically increasing circulating GH whilst inhibiting somatic growth (reviewed in Holloway \& Leatherland 1998). In addition, $\mathrm{E}_{2}$ has direct effects on igf1 and insulin-like growth factor-binding protein (igfbp) expression in hepatocytes (Riley et al. 2004). In fhm exposed to $\mathrm{E}_{2}$, pituitary $g h$ expression was unaffected but, in goldfish, $\mathrm{E}_{2}$ increased pituitary GH levels without any changes in steady-state pituitary $g h$ mRNA levels, suggesting that the actions of $\mathrm{E}_{2}$ on $\mathrm{GH}$ are not at the level of transcription (Zou et al. 1997). Moreover, the absence of oestrogen-response elements on teleost gh genes (Chen et al. 1994, Xiong et al. 1994) suggests that $\mathrm{E}_{2}$ does not increase GH through direct genomic effects. Down-regulated hepatic ghr expression, rather than plasma GH, has also been attributed to decreased plasma IGF-I by $\mathrm{E}_{2}$ (McCormick et al. 2005). Our observations do not concur with this hypothesis, but the nature of $g h r$ translation means a direct correlation between $g h r m R N A$ and ghr protein cannot be assumed (see Calduch-Giner et al. 2003). Since the liver is the main source of circulating IGF-I, decreased hepatic IGF1 synthesis also has the potential for wide-reaching effects in the body via disruption of the actions of plasma IGF-I in other body tissues.

Alterations in the normal functioning of the thyroid hormone and corticosteroid systems may provide an additional pathway by which environmental oestrogens compromise the growth and development of fish. For example, both $\mathrm{T}_{3}$ (Peng \& Peter 1997, Schmid et al. 2003) and F (reviewed in Mommsen et al. 1999) are regulatory hormones for the GH/IGF system. Suppressive effects of $E_{2}$ on thyroidal activity have been shown in fish, most notably through reductions in plasma $T_{3}$,

Figure 3 Expression of fhm gh, ghr, igf1, igf1r, thra, thrb, and gr in (A) liver, (B) gonad, (C) brain, (D) pituitary, (E) intestine and (F) gill of adult male $(\mathrm{m})$ and female $(\mathrm{f}) \mathrm{fhm}$ following waterborne exposure to $35 \mathrm{ng} 17 \beta$-oestradiol $\left(\mathrm{E}_{2}\right) / \mathrm{l}$. Fhm gh expression was only analysed in pituitary and gonad because it was undetectable in the other tissues studied. The results are represented as means \pm s.E.M. and expressed as the fold-increase in relative mRNA expression from the control. Relative mRNA expression was determined as the ratio of target gene mRNA/rp/8 mRNA. Each treatment group consisted of eight male and eight female fish and each fish was analysed in duplicate. Statistically significant differences in fold-changes in relative gene expression between control and treated fish for each sex for each tissue type are denoted by an asterix $(P<0 \cdot 05$, Student's $t$-test). 
the active thyroid hormone (e.g. Cyr et al. 1988, Mercure et al. 2001, Qu et al. 2001, McCormick et al. 2005), although responses were highly variable between studies. In rat, $\mathrm{E}_{2}$ also decreased serum $\mathrm{T}_{3}$ (but not $\mathrm{T}_{4}$ ) levels (probably through an inhibitory effect of $E_{2}$ on deiodinase conversion of bioinactive $\mathrm{T}_{4}$ to bioactive $\mathrm{T}_{3}$ ), and may influence the hypothalamic/pituitary setpoint for the negative feedback effect of thyroid hormone on thyroid stimulating hormone secretion (Schmutzler et al. 2004, Seidlova-Wuttke et al. 2005). There is also evidence from salmonids that, through contrasting effects at multiple sites on the hypothalamus-pituitary-interrenal axis, $\mathrm{E}_{2}$ regulates $\mathrm{F}$ production from the fish interrenal. In vitro, $\mathrm{E}_{2}$ suppressed the ability of the rainbow trout interrenal to synthesise F (McQuillan et al. 2003), but in vivo it had a stimulatory effect elevating plasma $F$ through an increase in plasma adrenocorticotrophic hormone (Pottinger et al. 1996), the pituitary hormone which is the main secretagogue for F. In this work, $\mathrm{E}_{2}$ affected $t h r$ expression in liver, gonad, pituitary and gill (see later), and $g r$ expression in gonad and pituitary, the expression of which is auto-regulated by their ligands (e.g. Tata et al. 1993), but these effects were highly sex- and tissue-specific and, for $t h r s$, different for each thr subtype. Measurements of plasma $\mathrm{T}_{3}$ and $\mathrm{F}$ levels in fhm exposed to $\mathrm{E}_{2}$, together with a more complete understanding of the differential roles of THR and GR subtypes in fish tissues and their ligand regulation, are therefore required to more fully evaluate the effects of environmental oestrogens on these axes in fhm.

Since reproductive roles for GH (reviewed in LeGac et al. 1993), IGFs (Huang et al. 1998, Weber \& Sullivan 2005), thyroid hormones (Soyano et al. 1993, Tambets et al. 1997) and F (reviewed in Mommsen et al. 1999) have all been demonstrated in fish, gonadal changes in their expression further indicate multiple pathways of oestrogen effect on sexual development. Given the lack of knowledge on the function of locally produced $\mathrm{GH}$ and IGF-I, and of the roles of THRs and GRs in the gonad, however, it is difficult to interpret these effects. Gonadal $g h$ expression was clearly up-regulated by $\mathrm{E}_{2}$ in both males and females, which may have been a direct effect of $E_{2}$, via changes in the expression of gonadal esrs, and/or may have been a result of increased plasma GH levels associated with $\mathrm{E}_{2}$ exposure, since $\mathrm{GH}$ treatment increases gonadal gh mRNA (Biga et al. 2004). Effects of $\mathrm{E}_{2}$ further downstream in the GH/IGFI axis were, however, sex specific with inhibition of the IGF system (via decreased gonadal $g h r$ and $i g f l$ ) in females, but no further responses in males. In females, decreased gonadal igfl expression, combined with decreased hepatic igf1 expression (and therefore plasma IGF-I levels), may be central to the $\mathrm{E}_{2}$-inhibited ovarian growth observed as IGF-I drives oocyte maturation (Negatu et al. 1998). Treatment of female seabream with $\mathrm{E}_{2}$ has been shown to inhibit the IGF system (via a decreased ovarian igfl and an increased $i g f b p 2$ expression), but the effects were related to the reproductive phase (Gioacchini et al. 2005). While these inhibitory effects on the IGF system were seen in fish exposed during the period prior to sexual maturity, during the reproductive period $\mathrm{E}_{2}$-induced gonadal igfl expression and also expression of gonadal insulin-like growth factor-2 (igf2) and igflr. Interestingly, the effects of GH treatment on the ovarian IGF system also varied depending on reproductive status, with GH inducing ovarian igf1 expression in fish prior to sexual maturity, but inhibiting the ovarian IGF system in reproductively active fish by reducing igf 2 and igflr mRNA and inducing igfbp 2 mRNA (Gioacchini et al. 2005). Sex differences in the effects of $\mathrm{E}_{2}$ on gonadal genes may be due to the differential effects of $\mathrm{E}_{2}$ on gonadal esr1 expression in male and female gonad.

For the most part, the neural expression of our target genes (and steroid hormone receptors) was unchanged by exposure to $\mathrm{E}_{2}$, while, in the pituitary, the target genes were highly responsive to $\mathrm{E}_{2}$. The exception was for $i g f 1$, whose expression in the brain was up-regulated by $E_{2}$ in both males and females. The widespread localisation of igfl expression in the brain in mammals has argued for a general role of brain IGFI in neuronal proliferation, growth and survival (Bondy \& Lee 1993), which is supported by IGF-I and IGF-IR mRNA localisation studies in teleost brain (Perrot et al. 1999, Smith et al. 2005). $\mathrm{E}_{2}$ may have a role in regulating these actions. Up-regulation of the igfl gene in brain and pituitary may also reflect feedback effects of IGF-I on the hypothalamic pathways which regulate pituitary GH secretion, or directly on GH-producing cells in the pituitary, since IGF-I inhibits pituitary GH transcription and release (Blaise et al. 1995, see review in Fruchtman et al. 2000). Brain igf1 up-regulation by $\mathrm{E}_{2}$ in female fish may additionally be connected with the potentiating effect of IGF-I on pituitary gonadotrophin responses to gonadotrophinreleasing hormone involving paracrine pathways (Weil et al. 1999). It is possible that the general lack of effects of $\mathrm{E}_{2}$ on the brain observed in fhm in this study was due to the fact that we measured whole brain expression of target genes, and this may have masked any effects of $\mathrm{E}_{2}$ in specific neural regions.

In addition to assessing the effects of $E_{2}$ on reproductive tissues (liver, gonad, brain and pituitary), we also looked for possible wider effects of $\mathrm{E}_{2}$ on other body tissues (gill and intestine) which have received very little, if any, attention in environmental oestrogen research. The fact that exposure to $E_{2}$ also affects the expression of key endocrine genes in these tissues supports our proposal that a far broader approach to understanding the effects of environmental oestrogens in the body is required. In the intestine, none of our 
target genes was affected by $\mathrm{E}_{2}$, but there was a clear down-regulation in expression of intestinal esr2a (formerly known as oestrogen receptor $\beta 2 / \gamma$ ). We have previously shown that, in fhm, esr $2 a$ is most highly expressed in intestine (Filby \& Tyler 2005), implying important roles in activating $\mathrm{E}_{2}$-target genes in this tissue. Further work on other oestrogen-regulated genes is required to determine the implications of $\mathrm{E}_{2}$ exposure on intestinal function.

Suppression of gill igfl expression (and potentially plasma IGF-I) due to $\mathrm{E}_{2}$ treatment highlights the potential for a reduced osmoregulatory ability in fhm exposed to environmental oestrogens. Although the osmoregulatory physiology of fhm is unknown, in other teleost species igf1 mRNA has been identified in osmoregulatory organs (gill and kidney), and osmoregulatory challenges increase its expression (Sakamoto \& Hirano 1993). Furthermore, there is evidence that IGF-I (both plasma and local) is a hormonal mediator of the hypo-osmoregulatory actions of GH (McCormick et al. 1991, Madsen \& Bern 1993, Sakamoto \& Hirano 1993). Previous studies have reported that $\mathrm{E}_{2}$, and other environmental oestrogens, impact on osmoregulation both in salmonid (Madsen et al. 1997, 2004, Stoffel et al. 2000, Arsenault et al. 2004, McCormick et al. 2005) and non-salmonid (Vijayan et al. 2001) species, and suppressed plasma levels of IGF-I were identified as the likely mechanism (McCormick et al. 2005). Our work supports this theory and provides new evidence for a direct effect of $\mathrm{E}_{2}$ on local IGF-I production in gill and this is likely to be an additional mechanism of $\mathrm{E}_{2}$-related osmoregulatory effects. A possible pathway for this may be via the down-regulation of esr 1 observed in the gill. In many teleost species, thyroid hormones also support the hypo-osmoregulatory actions of GH (McCormick 2001), and the down-regulation observed in gill thra of fhm exposed to $\mathrm{E}_{2}$ may also be a pathway for $\mathrm{E}_{2}$-related osmoregulatory effects, especially since negative effects of $\mathrm{E}_{2}$ on the thyroid axis have already been implicated in perturbations in osmoregulation (McCormick et al. 2005).

To conclude, our data show that exposure to $\mathrm{E}_{2}$ has multiple and wide-ranging effects on the expression of genes involved in the regulation of a broad range of physiological functions, and not just those central to reproduction. These findings are consistent with the evidence for a high degree of interplay between signalling pathways involved in the control of growth, development, thyroid and interrenal function, and reproduction. The gene responses to $\mathrm{E}_{2}$ were highly complex (frequently both sex- and tissue-specific), highlighting the importance of a more complete understanding of the roles, and modes of action, of these proteins in each tissue if we are to fully appreciate the health implications of environmental oestrogen exposure for fish. Our data, together with recent reports in which two other important environmental oestrogens, NP and bisphenol A, have been shown to affect the GH-IGF and/or thyroid hormone systems in fish (Yadetie \& Male 2002, Suzuki \& Hattori 2003, Arsenault et al. 2004), raises further concerns about the presence and potential for detrimental health effects of sex steroids and their mimics/antagonists in aquatic environment.

\section{Acknowledgements}

We would like to acknowledge John Sumpter at Brunel University for kindly commenting on an early version of the manuscript.

\section{Funding}

A L F was funded on a PhD studentship from the British Biotechnology and Biosciences Research Council (BBSRC). K L T was funded by the U.K. Environment Agency and AstraZeneca on a grant awarded to C R T There is no conflict of interest that would prejudice the impartiality of this research.

\section{References}

Ankley GT \& Villeneuve DL 2006 The fathead minnow in aquatic toxicology: past, present and future in press. Aquatic Toxicology $\mathbf{7 8}$ 91-102.

Arai R \& Tamaoki B 1967 Steroid biosynthesis of $11 \beta$-hydroxytestosterone and 11-ketotestosterone in the testis of rainbow trout, Salmo gairdneri. Canadian Journal of Biochemistry 45 1191-1195.

Arsenault JT, Fairchild WL, MacLatchy DL, Burridge L, Haya K \& Brown SB 2004 Effects of water-borne 4-nonylphenol and 17betaestradiol exposures during parr-smolt transformation on growth and plasma IGF-I of Atlantic salmon (Salmo salar L.). Aquatic Toxicology 66 255-265.

Baron D, Fostier A, Breton B \& Guiguen Y 2005 Androgen and estrogen treatments alter steady state messenger RNA (mRNA) levels of testicular steroidogenic enzymes in the rainbow trout Molecular Reproduction and Development 71 471-479.

Baronti C, Curini C, D’Ascenzo G, Di Corcia A, Gentili A \& Samperi R 2000 Monitoring natural and synthetic estrogens at activated sludge sewage treatment plants and in receiving river water. Environmental Science and Technology 24 5059-5066.

Biga PR, Schelling GT, Hardy RW, Cain KD, Overturf K \& Ott TL 2004 The effects of recombinant bovine somatotropin (rbST) on tissue IGF-I, IGF-I receptor, and GH mRNA levels in rainbow trout, Oncorhynchus mykiss. General and Comparative Endocrinology 135 324-333.

Bjornsson BT 1997 The biology of salmon growth hormone: from daylight to dominance. Fish Physiology and Biochemistry 17 9-24.

Blaise O, Weil C \& LeBail PY 1995 Role of IGF-I in the control of GH secretion in rainbow trout (Oncorhynchus mykiss). Growth Regulation 5 142-150.

Bondy CA \& Lee WH 1993 Patterns of insulin-like growth factor and IGF receptor gene expression in the brain. Annals of New York Academy of Science 692 33-43.

Brent GA 1996 Thyroid hormones (T4, T3). In Endocrinology: Basic and Clinical Principles, pp 32-67. Ed S Melmed. Totowa: Humana Press. 
Butler AA \& Le Roith D 2001 Control of growth by the somatotropic axis: growth hormone and the insulin-like growth factors have related and independent roles. Annual Reviews in Physiology 63 141-164.

Calduch-Giner JA, Mingarro M, Vega-Rubin de Celis S, Boujard D \& Perez-Sanchez J 2003 Molecular cloning and characterization of gilthead sea bream (Sparus autata) growth hormone receptor (GHR). Assessment of alternative splicing. Comparative Biochemistry and Physiology Part B 136 1-13.

Cavari B, Funkenstein B, Chen TT, Gonzalez-Villasenor LI \& Schartl M 1993 Effect of growth hormone on the growth rate of gilthead seabream (Sparus aurata), and use of different constructs for the production of transgenic fish. Aquaculture 111 189-197.

Chen TT, Marsh A, Shamblott M, Chan KM, Tang YL, Cheng CM \& Yang BY 1994 Structure and evolution of fish growth hormone and insulin-like growth factor genes. In Fish Physiology XIII - Volume XIII Bioenergetics and Growth, pp 179-209. Eds WS Hoar, DJ Randall \& JR Brett. San Diego/New York: Academic Press.

Conley AJ \& Bird LM 1997 The role of cytochrome P450 17 $\alpha$ -

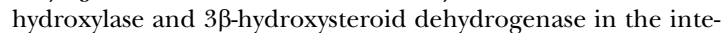
gration of gonadal and adrenal steroidogenesis via the $\Delta 5$ and $\Delta 4$ pathways of steroidogenesis in mammals. Biology of Reproduction $\mathbf{5 6}$ 789-799.

Cyr DG, MacLatchy DL \& Eales JG 1988 The influence of short-term 17 beta-estradiol treatment on plasma T3 levels and in vitro hepatic T4 $5^{\prime}$-monodeiodinase activity in immature rainbow trout, Salmo gairdneri. General and Comparative Endocrinology 69 431-438.

Desbrow C, Routledge EJ, Brighty GC, Sumpter JP \& Waldock M 1998 Identification of estrogenic chemicals in STW effluent, 1. Chemical fractionation and in vitro biological screening. Environmental Science and Technology 32 1549-1558.

Dreze V, Monod G, Cravedi JP, Biagianti-Risbourg S \& Le Gac F 2000 Effects of 4-nonylphenol on sex differentiation and puberty in mosquito fish (Gambusia holbrooki). Ecotoxicology 9 93-103.

Durlinger AL, Visser JA \& Themmen AP 2002 Regulation of ovarian function: the role of anti-Mullerian hormone. Reproduction 124 601-609.

Filby AL \& Tyler CR 2005 Molecular characterization of estrogen receptors $1,2 \mathrm{a}$ and $2 \mathrm{~b}$ and their tissue and ontogenic expression profiles in fathead minnow (Pimephales promelas). Biology of Reproduction 73 648-662.

Fruchtman S, Jackson L \& Borski R 2000 Insulin-like growth factor I disparately regulates prolactin and growth hormone synthesis and secretion: studies using the teleost pituitary model. Endocrinology 141 2886-2894.

Gioacchini G, Cardinali M, Maradonna F, Funkenstein B, Mosconi G \& Carnevali O 2005 Hormonal control of the IGF system in the sea bream ovary. Annals of the New York Academy of Science 1040 320-322.

Govoroun M, McMeel OM, Mecherouki H, Smith TJ \& Guiguen Y 2001 17Beta-estradiol decreases steroidogenic enzyme messenger ribonucleic acid levels in the rainbow trout testis. Endocrinology 142 1841-1848.

Halm S, Pounds N, Maddix S, Rand-Weaver M, Sumpter JP, Hutchinson TH \& Tyler CR 2002 Exposure to exogenous 17betaoestradiol disrupts p450aromB mRNA expression in the brain and gonad of adult fathead minnows (Pimephales promelas). Aquatic Toxicology 60 285-299.

Harvey S, Johnson CDM, Sharma P, Sanders EJ \& Hull KL 1998 Growth hormone: a paracrine growth factor in embryonic development. Comparative Biochemistry and Physiology Part C 119 305-315.

Holloway AC \& Leatherland JF 1998 Neuroendocrine regulation of growth hormone secretion in teleost fishes with emphasis on the involvement of gonadal steroids. Reviews in Fish Biology and Fisheries 8 409-429.

Hou YY, Suzuki Y \& Aida K 1999 Effects of steroid hormones on immunoglobulin M (IgM) in rainbow trout, Oncorhynchus mykiss. Fish Physiology and Biochemistry 20 155-162.
Huang YS, Rousseau K, Le Belle N, Vidal B, Burzawa-Gerard E, Marchelidon J \& Dufor S 1998 Insulin-like growth factor I stimulates gonadotropin production from eel pituitary cells: a possible metabolic signal for induction of puberty. Journal of Endocrinology 159 43-52.

Jobling S, Nolan M, Tyler CR, Brighty G \& Sumpter JP 1998 Widespread sexual disruption in wild fish. Environmental Science and Technology 32 2498-2506.

Jobling S, Coey S, Whitmore JG, Kime DE, Van Look KJ, McAllister BG, Beresford N, Henshaw AC, Brighty G, Tyler CR \& Sumpter JP $2002 a$ Wild intersex roach (Rutilus rutilus) have reduced fertility. Biology of Reproduction 67 515-524.

Jobling S, Beresford N, Nolan M, Rodgers-Gray T, Brighty GC, Sumpter JP \& Tyler CR 2002b Altered sexual maturation and gamete production in wild roach (Rutilus rutilus) living in rivers that receive treated sewage effluents. Biology of Reproduction 66 272-281.

Jones JI \& Clemmons DR 1995 Insulin-like growth factors and their binding proteins: biological actions. Endocrine Reviews 16 3-29.

Josso N, Racine C, di Clemente N, Rey R \& Xavier F 1998 The role of anti Mullerian hormone in gonadal development. Molecular and Cellular Endocrinology 145 3-7.

Kopchick JJ \& Andry JM 2000 Growth hormone (GH), GH receptor, and signal transduction. Molecular Genetics and Metabolism 71 293-314.

Law WY, Chen WH, Song YL, Dufour S \& Chang CF 2001 Differential in vitro suppressive effects of steroids on leukocyte phagocytosis in two teleosts, tilapia and common carp. General and Comparative Endocrinology 121 163-172.

Lazar MA 2003 Thyroid hormone action: a binding contract. Journal of Clinical Investigation 112 497-499.

LeGac F, Blaise O, Fostier A, Lebail PY, Loir M, Mourot B \& Weil C 1993 Growth hormone (GH) and reproduction - a review. Fish Physiology and Biochemistry 11 219-232.

Liu D, LeDrean Y, Ekker M, Xiong F \& Hew CL 1997 Teleost FTZ-F1 homolog and its splicing variant determine the expression of the salmon gonadotropin II beta subunit gene. Molecular Endocrinology $11877-890$.

MacKay ME, Raelson J \& Lazier CB 1996 Up-regulation of estrogen receptor mRNA and estrogen receptor activity by estradiol in liver of rainbow trout and other teleostean fish. Comparative Biochemistry and Physiology Part C 115 201-209.

MacLatchy DL, Courtenay SC, Rice CD \& Van der Kraak GJ 2003 Development of a short-term reproductive endocrine bioassay using steroid hormone and vitellogenin end points in the estuarine mummichog (Fundulus heteroclitus). Environmental Toxicology and Chemistry 22 996-1008.

Madsen SS \& Bern HA 1993 In vitro effects of insulin-like growth factorI on gill $\mathrm{Na}^{+}, \mathrm{K}^{+}$-ATPase in coho salmon, Oncorhynchus kisutch. Journal of Endocrinology 138 23-30.

Madsen SS, Mathiesen AB \& Korsgaard B 1997 Effects of $17 \beta$-oestradiol and 4-nonylphenol on smoltification and vitellogenesis in Atlantic salmon (Salmo salar). Fish Physiology and Biochemistry 17 303-312.

Madsen SS, Skovbolling S, Nielsen C \& Korsgaard B 2004 17-Beta estradiol and 4-nonylphenol delay smolt development and downstream migration in Atlantic salmon. Salmo salar. Aquatic Toxicology 68 109-120.

Magliulo L, Schreibman MP, Cepriano J \& Ling J 2002 Endocrine disruption caused by two common pollutants at 'acceptable' concentrations. Neurotoxicology and Teratology 24 71-79.

Marchand O, Govoroun M, D'Cotta H, McMeel O, Lareyre JJ, Bernot A, Laudet V \& Guiguen Y 2000 DMRT1 expression during gonadal differentiation and spermatogenesis in the rainbow trout. Oncorhynchus mykiss. Biochimica et Biophysica Acta 1493 180-187.

McCormick SD 2001 Endocrine control of osmoregulation in teleost fish. American Zoologist 41 781-794.

McCormick SD, Sakamoto T, Hasegawa S \& Hirnao T 1991 Osmoregulatory actions of insulin-like growth factor I in rainbow trout (Oncorhynchus mykiss). Journal of Endocrinology 130 87-92. 
McCormick SD, O'Dea MF, Moeckel AM, Lerner DT \& Bjornsson BT 2005 Endocrine disruption of parr-smolt transformation and seawater tolerance of Atlantic salmon by 4-nonylphenol and $17 \beta$ estradiol. General and Comparative Endocrinology 142 280-288.

McQuillan HJ, Lokman PM \& Young G 2003 Effects of sex steroids, sex and sexual maturity on cortisol production: an in vitro comparison of Chinook salmon and rainbow trout interrenals. General and Comparative Endocrinology 133 154-163.

Mercure F, Holloway AC, Tocher DR, Sheridan MA, Van der Kraak G \& Leatherland JF 2001 Influence of plasma lipid changes in response to $17 \beta$-oestradiol stimulation on plasma growth hormone, somatostatin, and thyroid hormone levels in immature rainbow trout. Journal of Fish Biology $\mathbf{5 9}$ 605-615.

Mommsen TP, Vijayan MM \& Moon TW 1999 Cortisol in teleosts: dynamics, mechanisms of action, and metabolic regulation. Reviews in Fish Biology and Fisheries 9 211-268.

Negatu Z, Hsiao SM \& Wallace RA 1998 Effects of insulin-like growth factor-I on final oocyte maturation and steroid production in Fundulus heteroclitus. Fish Physiology and Biochemistry 19 13-21.

Panter GH, Hutchinson TH, Lange R, Lye CM, Sumpter JP, Zerulla M \& Tyler CR 2002 Utility of a juvenile fathead minnow screening assay for detecting (anti-) estrogenic substances. Environmental Toxicology and Chemistry 21 319-326.

Peng C \& Peter RE 1997 Neuroendocrine regulation of growth hormone secretion and growth in fish. Zoological Studies 36 79-89.

Perez-Sanchez J 2000 The involvement of growth hormone in growth regulation, energy homeostasis and immune function in the gilthead sea bream (Sparus autata): a short review. Fish Physiology and Biochemistry 22 135-144.

Perrot V, Moiseeva EB, Gozes Y, Chan SJ, Ingleton P \& Funkenstein B 1999 Ontogeny of the insulin-like growth factor system (IGF-I, IGFII, and IGF-IR) in gilthead seabream (Sparus aurata): expression and cellular localization. General and Comparative Endocrinology 116 $445-460$.

Pottinger TG, Carrick TR, Hughes SE \& Balm PHM 1996 Testosterone, 11-ketotestosterone, and estradiol-17 $\beta$ modify baseline and stressinduced interrenal and corticotropic activity in trout. General and Comparative Endocrinology 104 284-295.

Power DM, Llewellyn L, Faustino M, Nowell MA, Bjornsson BJ, Einarsdottir IE, Canario AVM \& Sweeney GE 2001 Thyroid hormones in growth and development of fish. Comparative Biochemistry and Physiology Part C 130 447-459.

Qu X, Nagae M, Adachi S \& Yamauchi K 2001 Effect of estradiol-17 beta on pituitary-thyroidal axis of Japanese eel (Anguilla japonica). Acta Oceanologica Sinica 20 585-596.

Rasmussen R 2001 Quantification on the LightCycler. In Rapid Cycle Real-Time PCR, Methods and Applications, pp 21-34. Eds S Meuer, C Wittwer \& K Nakagawara. Heidelberg: Springer Press.

Rasmussen TH, Andreassen TK, Pedersen SN, Van der Ven LTM, Bjerregaard P \& Korsgaard B 2002 Effects of waterborne exposure of octylphenol and estrogen on pregnant viviparous eelpout (Zoarces viviparous) and her embryos in ovario. Journal of Experimental Biology 205 3857-3876.

Riley LG, Hirano T \& Grau EG 2004 Estradiol-17 $\beta$ and dihydrotestosterone differentially regulate vitellogenin and insulin-like growth factor-I production in primary hepatocytes of the tilapia Oreochromis mossambicus. Comparative Biochemistry and Physiology Part C 138 177-186.

Rodgers-Gray TP, Jobling S, Kelly C, Morris S, Brighty G, Waldock MJ, Sumpter JP \& Tyler CR 2001 Exposure of juvenile roach (Rutilus rutilus) to treated sewage effluent induces dose-dependent and persistent disruption in gonadal duct development. Environmental Science and Technology 35 462-470.

Rotchell JM \& Ostrander GK 2003 Molecular markers of endocrine disruption in aquatic organisms. Journal of Toxicology and Envrionmental Health Part B 6 453-495.
Routledge EJ \& Sumpter JP 1996 Estrogenic activity of surfactants and some of their degradation products assessed using a recombinant yeast screen. Environmental Toxicology and Chemistry 15 241-248.

Sakamoto T \& Hirano T 1993 Expression of insulin-like growth factor I gene in osmoregulatory organs during seawater adaptation of the salmonids fish: possible mode of osmoregulatory action of growth hormone. PNAS 90 1912-1916.

Schmid AC, Lutz I, Kloas W \& Reinecke M 2003 Thyroid hormone stimulates hepatic IGF-I mRNA expression in a bony fish, the tilapia Oreochromis mossambicus, in vitro and in vivo. General and Comparative Endocrinology 130 129-134.

Schmutzler C, Hamann I, Hofmann PJ, Kovacs G, Stemmler L, Mentrup B, Schomburg L, Ambrugger P, Gruters A, SeidlovaWuttke D, Jarry H, Wuttke W \& Kohrle J 2004 Endocrine active compounds affect thyrotropin and thyroid hormone levels in serum as well as endpoints of thyroid hormone action in liver, heart and kidney. Toxicology 205 95-102.

Seidlova-Wuttke D, Jarry H, Christoffe J, Rimoldi G \& Wuttke W 2005 Effects of bisphenol-A (BPA), dibutylphtalate (DBP), benzophenone-2 (BP2), procymidone (Proc), and linurone (Lin) on fat tissue, a variety of hormones and metabolic parameters: A 3 months comparison with effects of estradiol (E2) in ovariectomized (ovx) rats. Toxicology 213 13-24.

Simpson ER, Mahendroo MS, Means GD, Kilgore MW, Hinshelwood MM, Graham-Lorence S, Amarneh B, Ito Y, Fisher CR \& Michael MD 1994 Aromatase cytochrome P450, the enzyme responsible for estrogen biosynthesis. Endocrine Reviews 15 342-355.

Smith A, Chan SJ \& Gutierrez J 2005 Autoradiographic and immunohistochemical localization of insulin-like growth factor-I receptor binding sites in brain of the brown trout, Salmo trutta. General and Comparative Endocrinology 141 203-213.

Sonnenschein C \& Soto AM 1998 An updated review of environmental estrogen and androgen mimics and antagonists. Journal of Steroid Biochemistry and Molecular Biology 65 143-150.

Soyano K, Saito T, Nagae M \& Yamauchi K 1993 Effects of thyroid hormone on gonadotropin-induced steroid production in medaka, Oryzias latipes, ovarian follicles. Fish Physiology and Biochemistry 11 265-272.

Stoffel MH, Wahli T, Friess AE \& Burkhardt-Holm P 2000 Exposure of rainbow trout (Oncorhynchus mykiss) to nonylphenol is associated with an increased chloride cell fractional surface area. Schweizer Archiv fur Tierheikunde 142 263-267.

Sumpter JP \& Jobling S 1995 Vitellogenesis as a biomarker for estrogenic contamination of the aquatic environment. Environmental Health Perspectives 103 173-178.

Suzuki N \& Hattori A 2003 Bisphenol A suppressed osteoclastic and osteoblastic activities in the cultured scales of goldfish. Life Sciences 73 2237-2247.

Tambets M, Molsa H \& Saat T 1997 Effects of triiodothyronine on in vitro maturation of verdace (Coregonus albula) oocytes under unfavourable influences. Annales Zoologici Fennici 34 213-216.

Tata JR, Baker BS, Machuca I, Rabelo EM \& Yamauchi K 1993 Autoinduction of nuclear receptor genes and its significance. Journal of Steroid Biochemistry and Molecular Biology 46 105-119.

Ternes TA, Stumpf M, Mueller J, Haberer K, Wilken RD \& Servos M 1999 Behaviour and occurrence of estrogens in municipal sewage treatment plants. I. Investigations in Germany, Canada and Brazil. Science of the Total Environment 225 81-90.

Tsai MJ \& O'Malley BW 1994 Molecular mechanisms of action of steroid/thyroid receptor superfamily members. Annual Reviews in Biochemistry 63 451-486.

Tyler CR, Jobling S \& Sumpter JP 1998 Endocrine disruption in wildlife: a critical review of the evidence. Critical Reviews in Toxicology 28 319-361.

Tyler CR, van Aerle R, Hutchinson TH, Maddix S \& Trip H 1999 An in vivo testing system for endocrine disruptors in fish early life stages using induction of vitellogenin. Environmental Toxicology and Chemistry 18 337-347. 
Van den Belt K, Verheyen R \& Witters H 2003 Effects of $17 \alpha-$ ethinylestradiol in a partial life-cycle test with zebrafish (Danio rerio): effects on growth, gonads and female reproductive success. The Science of the Total Environment 309 127-137.

Versonnen BJ \& Janssen CR 2004 Xenoestrogenic effects of esthinylestradiol in zebrafish (Danio rerio). Environmental Toxicology 19 198-206.

Vijayan MM, Takemura A \& Mommsen TP 2001 Estradiol impairs hypoosmoregulatory capacity in the euryhaline tilapia, Oreochromis mossambicus. American Journal of Physiology 281 R1161-R1168.

Wang R \& Belosevic M 1994 Estradiol increases susceptibility of goldfish to Trypanosoma danilewskyi. Developmental and Comparative Immunology 18 377-387.

Weber GM \& Sullivan CV 2005 Insulin-like growth factor-I induces oocyte maturational competence but not meiotic resumption in white bass (Morone chrysops) follicles in vitro: evidence for rapid evolution of insulin-like growth factor action. Biology of Reproduction 72 1177-1186.

Weil C, Carre F, Blaise O, Breton B \& Le Bail RY 1999 Differential effect of insulin-like growth factor I on in vitro gonadotropin (I and II) and growth hormone secretions in rainbow trout (Oncorhynchus mykiss) at different stages of the reproductive cycle. Endocrinology 140 2054-2062.

Wendelaar Bonga SE 1997 The stress response in fish. Physiological Reviews 77 591-625.

Xiong F, Suzuki K \& Hew CL 1994 Control of teleost gonadotropin gene expression. In Fish Physiology XIII - Volume XIII - Bioenergetics and Growth, pp 135-158. Eds WS Hoar, DJ Randall \& JR Brett. San Diego/New York: Academic Press.

Yadetie F \& Male R 2002 Effects of 4-nonylphenol on gene expression of pituitary hormones in juvenile Atlantic salmon (Salmo salar). Aquatic Toxicology 58 113-129.

Zou JJ, Trudeau VL, Cui Z, Brechin J, Mackenzie K, Zhu Z, Houlihan DF \& Peter RE 1997 Estradiol stimulates growth hormone production in female goldfish. General and Comparative Endocrinology 106 102-112.

Received in final form 28 March 2006

Accepted 26 April 2006

Made available online as an Accepted Preprint 27 April 2006 